\title{
An Explicit Review on Quantitative Estimation of Candesartan Cilexetil Employing Various Analytical Techniques
}

\author{
Shantanu Bandyopadhyay ${ }^{1 *}$, Lohit Bhuria' and Devi Lal ${ }^{2}$
}

${ }^{1}$ University Institute of Pharmaceutical Sciences, UGC Centre of Advanced Studies, Panjab University, Chandigarh 160 014, India

${ }^{2}$ Technical Assistant, DST-FIST Lab, University Institute of Pharmaceutical Sciences, Panjab University, Chandigarh 160 014 , India

\begin{abstract}
Angiotensin II Receptor type 1 antagonists have been widely used in treatment of various disorders like hypertension, heart failure, myocardial infarction and diabetic nephropathy. Over the years, varied analytical methods were developed both in biological fluids as well as dosage forms in order to estimate their desired pharmacological activity. Candesartan being highly lipohpilic with variable oral bioavailability, its estimation in biological fluids is very critical for establishing its subsequent therapeutic efficacy. A few UV spectrophotometeric and volatmmetric techniques have been reported to estimate candesartan in bulk formulations. Additionally, capillary electrophoresis methods provided qualitative and quantitative estimation of candesartan with a few methods being systematically optimized using experimental designs. Ultimately, an overview of different HPLC and LC-MS/MS methods explained the importance of the methods while estimating candesartan in various biological fluids (e.g. plasma, urine, etc.) as well as other studies like, stability studies. This review provides a bird's eye-view on the various analytical techniques employed for determination of candesartan in both in vitro and in vivo conditions.
\end{abstract}

Keywords: Candesartan; Spectrophotometry; HPLC; LC-MS/MS; Biological fluids

\section{Introduction}

Candesartan cilexetil (CC) is a long acting nonpeptide prodrug which selectively inhibits Angiotensin II Receptor type 1 causing reduction in blood pressure without altering the heart rate. Hence, it is therapeutically indicated in the chronic treatment of hypertension $[1,2]$. Further, it is effective and well tolerated when used either as monotherapy or in combination with other antihypertensive agents in patients with mild, moderate or severe hypertension [3,4]. It was approved by USFDA in September 2000 and presently marketed by AstraZeneca and Takeda Pharmaceuticals. Recent reports indicated its increased use with the published data signifying its benefit in the treatment of stroke, heart failure, diabetic renal disease and diabetic retinopathy [5]. Being a highly lipophilic drug ( $\log P=6.1)$ with low aqueous solubility of $5 \times 10^{-5}$ g.L. $\mathrm{L}^{-1}$, the drug is classified as BCS class II drug [6-8].

\section{Clinical Background}

The absolute oral bioavailability of CC is variable and reported to be about $15 \%$ and $42 \%$ due to incomplete absorption [8-10]. Also, the relative bioavailability of CC ( $8 \mathrm{mg}$ tablet) was found to be $34 \%$ when compared to oral solution $(8 \mathrm{mg})$. This low bioavailability is due to poor aqueous solubility leading to slow rate of absorption construing that dissolution is the limiting step for the rate and extent of absorption. In a study with single and repeated once-daily doses of CC in the dose range of 2-16 mg carried out in both younger (19-40 years) and elderly (65-78 years) healthy volunteers various pharmacokinetics parameters were determined. It was observed that AUC and $\mathrm{C}_{\max }$ showed doseproportional increment in the dose range of 2-16 mg indicating linear pharmacokinetics. Non-compartmental models do not appear to be appropriate for the analysis of candesartan pharmacokinetics. The terminal elimination half-life of CC was estimated in the range of 4 to 9 $h$. The time to reach peak candesartan concentrations $\left(T_{\max }\right)$ following tablet intake was approximately $4 \mathrm{~h}$ at all dose levels. Also, the plasma protein binding in humans was quite high $(>99 \%)$ with relatively low volume of distribution in healthy subjects (i.e., $0.13{\mathrm{~L} . \mathrm{kg}^{-1}}^{-1}$ ). After reaching systemic circulation candesartan is cleared mainly by kidneys and to a smaller extent by biliary or intestinal routes. Clinically effective doses of CC ranged between 8 and $32 \mathrm{mg}$. The antihypertensive effect with CC monotherapy increases with the dose but never exceeds $60 \%$ at a daily dose of $16 \mathrm{mg}$. However, at doses up to $32 \mathrm{mg}$ day, antihypertensive effect did not increase further [9,11-14].

\section{Physicochemical Properties}

Prior to the initiation of CC analysis, it is imperative to have a holistic knowledge of its structure as well as other physicochemical characteristics. CC is a tetrazole derivative and chemically is (+)-1-(cyclohexyloxycarbonyloxy) ethyl 2-ethoxy-1-[[2'- $(1 \mathrm{H}-$ tetrazol-5-yl)biphenyl-4-yl]methyl]-1H-benzimidazole-7-carboxylate (Figure 1) $[15,16]$. The chemical structure consists of a lipophilic substituent, i.e., tetrazolyl biphenylmethyl moiety and a carboxyl group [17]. Its molecular weight is 610.66 g.mol ${ }^{-1}$ with empirical formula $\mathrm{C}_{33} \mathrm{H}_{34} \mathrm{~N}_{6} \mathrm{O}_{6}$. It is a white to off-white powder which is highly soluble in dimethylsulfoxide; sparingly soluble in methanol, ethanol or physiological saline solution and practically insoluble in water. The

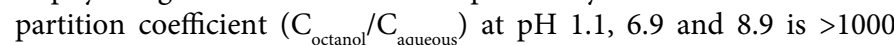
indicating high lipophilicity character [18]. The prodrug is a racemic mixture containing one chiral center at the cyclohexyloxycarbonyloxy ethyl ester group. Following oral administration, CC undergoes hydrolysis at the ester link to form the active drug, candesartan, which is achiral $[19,20]$. Candesartan in turns is converted to one inactive metabolite [13].

*Corresponding author: Shantanu Bandyopadhyay, University Institute of Pharmaceutical Sciences, UGC Centre of Advanced Studies, Panjab University, Chandigarh 160 014, India, E-mail: shantanuphd78@gmail.com

Received June 11, 2013; Accepted June 20, 2013; Published June 25, 2013

Citation: Bandyopadhyay S, Bhuria L, Lal D (2013) An Explicit Review on Quantitative Estimation of Candesartan Cilexetil Employing Various Analytical Techniques. Pharm Anal Acta 4: 254. doi:10.4172/2153-2435.1000254

Copyright: (c) 2013 Bandyopadhyay S, et al. This is an open-access article distributed under the terms of the Creative Commons Attribution License, which permits unrestricted use, distribution, and reproduction in any medium, provided the original author and source are credited. 


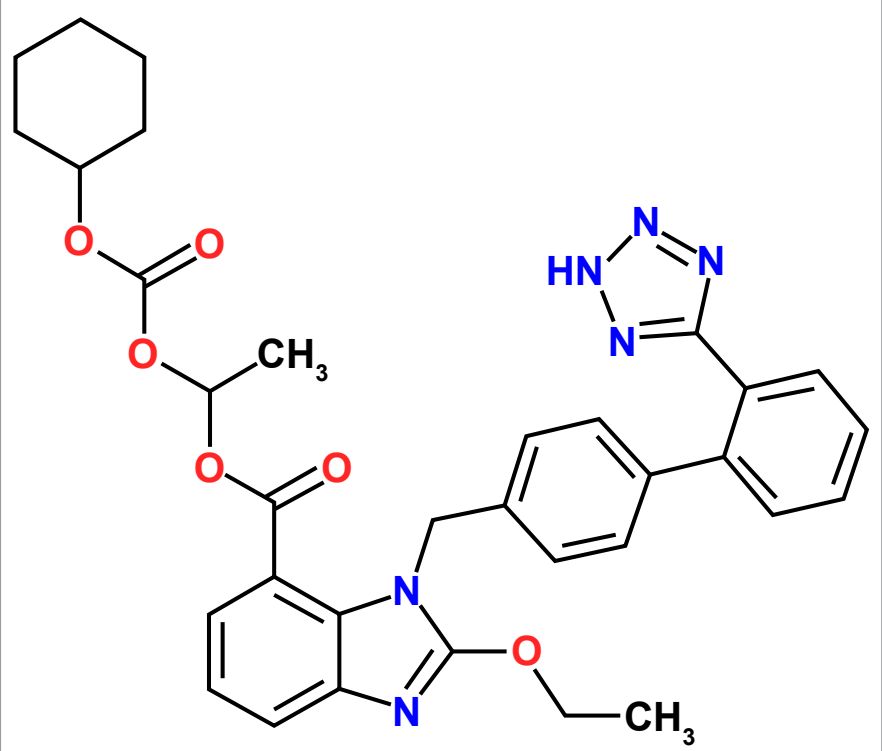

Figure 1: Chemical structure of candesartan cilexetil.

\section{Quantification Methods}

The pKa value of a drug is important as it is associated with the various biological processes such as body absorption, tissue distribution and elimination. Besides, the information about dissociation constants is also necessary to choose the optimal conditions for the extraction of these drugs from body fluids, which is an essential step to develop analytical methods for their determination [21]. As such a good correlation could be established by knowing the structure and the different acid-base species which in turn affects the absorption rate, the distribution profile and the excretion percentage. CC contains two acidic functional groups: a carboxyl and tetrazole moieties with their respective pKa values were calculated to be 6.0 [22]. In another citation the $\mathrm{pKa}$ values for carboxyl and tetrazole moieties were reported to be $5.3[12]$.

Till date, many analytical methods have been developed for the quantification and determination of candesartan in biological fluids and pharmaceutical dosage form. In most of the cases, the analysis in biological fluids were carried our employing HPLC or LC-MS/MS techniques. However, there are a few reports wherein CC has been determined using UV spectrophotometry and voltametric methods.

In one of the UV spectrophotometric methods, CC was assayed by first derivative and ratio derivative spectrophotometry in a mixture containing hydrochlorothiazide. Calibration curves were established in the range of $6.0-38.0 \mu \mathrm{g} . \mathrm{mL}^{-1}$ for $\mathrm{CC}$ and the method was found to be linear, precise and selective. The method was subsequently successfully applied to the pharmaceutical dosage form containing the abovementioned drug combination which also showed non-interference by the excipients [23]. Another UV spectrophotometric method was developed for CC estimation in bulk and formulations. Linearity of the method was validated in the range of $10.0-90.0 \mu \mathrm{g} \cdot \mathrm{mL}^{-1}$. The stability of CC was analyzed under various forced degradation conditions like, acid, alkali and neutral hydrolysis, oxidation, dry heat, UV light and photolytic degradation Subsequently, the method was found to be simple, sensitive and reliable with good precision and accuracy [24]. Another method focused on first derivative UV quantitative analysis in tablet dosage forms during in vitro dissolution testing. The highlight of the method was that the LOQ was $3.06 \mu \mathrm{g} \cdot \mathrm{ml}^{-1}$ when analyzed in the concentration range of $6.00-32.00 \mu \mathrm{g} \mathrm{ml}^{-1}$. Also, the percent recovery was also high concluding that the method passed all the parameters of quality control, i.e., accuracy, precision, sensitivity and selectivity [25].

Voltammetry is basically an electroanalytical method which is used to analyze an analyte by measuring the current with varying potential [26]. The reported methods utilized phosphate buffer as the supporting electrolyte. In the first reported method, CC was analyzed with different types of voltammetric techniques viz. cyclic, linear sweep, differential pulse, adsorptive stripping differential pulse, square wave and adsorptive stripping square wave. The analysis was carried out in the $\mathrm{pH}$ range 1.5-11.00. Further, differential pulse and square wave voltammetry techniques were studied to obtain a good sensitivity of the method. Finally, the method was validated and successfully applied for the analysis of CC tablets [27]. A simple and sensitive rapid adsorptive stripping voltammetric method was also developed for estimation of CC in pharmaceutical formulations. The linearity was observed between 0.25 and $1.34 \mu \mathrm{g} \mathrm{mL} \mathrm{L}^{-1}$. The method was finally validated for linearity, precision, accuracy and recovery [28]. However in another method, the authors used only squarewave adsorptive stripping square method for determination of CC in bulk and pharmaceutical formulations. The method involved a modification wherein CC was complexed with copper, $\mathrm{Cu}$ (II). Various experimental and instrumental parameters were investigated and optimized. Subsequently, the method was validated in terms of linearity, sensitivity, precision, accuracy, recovery, selectivity, robustness, and ruggedness [29]. Recently, a newly modified method based on continuous coulometric fast fourier transformation cyclic voltammetry was developed for CC determination. In this technique, a new sensor was designed based on silicon carbide nanoparticles and graphene nanosheets hybrid mixed with ionic liquid (1-Butyl3-methylimidazolium hexa fluorophosphate ([bmim][PF6]) on a glassy carbon electrode. The sensor exhibited good accuracy with high sensitivity and repeatability. Even, it had 55 days of long term stability with a decrease of $2.3 \%$ in the response. Scanning electron microscopy and impedance spectroscopy was used to characterize the electrode surface [30].

Capillary electrophoresis, also known as capillary zone electrophoresis separates the ionic species based on their charge, frictional forces and hydrodynamic radius [31]. Similar to voltammetry technique, phosphate buffer have been used as running electrolyte in all the reported capillary electrophoresis methods. Also, the detection of the ionic samples has been set at $214 \mathrm{~nm}$ using UV detector. Except one method, in all the other methods, a constant volateg of $25 \mathrm{kV}$ have been applied. To identity the sample components the instrument can be coupled with mass spectrometers or surface-enhanced raman spectroscopy. Finally, the reported methods have been validated for linearity of response, precision, reproducibility, and accuracy. Table 1 illustrates the four methods employed along with the various experimental conditions. Additionally, the technique is optimized using experimental design methodologies by applying three-level and four-factor full-factorial design in two cases and three-level and threefactor face-centred central composite design in one analysis [32-34] Also, CC was determined, both qualitatively and quantitatively, using micellar electrokinetic capillary chromatographic [34,35].

Although, the main advantages of previous mentioned methods are shorter analysis time, lesser solvents, low cost of analysis and widespread availability of the apparatus yet they cannot be applied 
for analysis in biological samples. Hence, in order to estimate CC in biological systems, it was imperative to develop HPLC and LC-MS/MS methods.

In the following discussions, different HPLC based analytical techniques were elaborated for the determination of CC in the biological fluids and dosage forms. Table 2 enumerates the various HPLC methods employed for CC estimation, till date.

CC was estimated employing column-switching HPLC wherein the zone of analyte's retention obtained from earlier column is transferred to another column by increasing the $\mathrm{pH}$ of the mobile phase. The method was used for determination CC and its metabolites in human serum and urine with good linearity, precision, accuracy and low LOQ. The versatility of method was further established from the results of stability studies [36]. In another column-switching method, using an FCV-2AH six-port valve, CC along with its two metabolites was analyzed in human serum. The metabolites were also analyzed in urine by gradient elution mode HPLC. The method were later on applied for conducting the clinical trials of CC [37].

A placebo-controlled, double-blind, four way crossover design for oral doses of 4,8 and $16 \mathrm{mg}$ of CC was carried out in healthy human volunteers. Following this blood samples were withdrawn periodically and various pharmacokinetic parameters were calculated. The study indicated that CC shows dose-dependent behavior in pharmacokinetic responses [38]. In another double-blind, crossover study, 12 healthy male volunteers received daily oral doses of $8 \mathrm{mg}$ CC. A liquid chromatography assay was employed to determine the plasma concentrations of CC and subsequent pharmacokinetic parameters [39].

Owing to extensive pharmacokinetic and clinical studies, a fast and easy HPLC method was reported for determination of CC in biological fluids. In one of the assays liquid-liquid extraction was carried out with dichloromethane-diethyl ether (1:4, v/v) and analyzed with fluorometric detection. The method was applied to human plasma and urine samples which were further used for biopharmaceutical and clinical studies in man. For efficient extraction of samples, a guard column was also utilized. The method was quantified with high precision and strikingly, LOQ was found to be quite low. Also, the CC samples were stable under different storage conditions [40].

$\mathrm{CC}$ was also analyzed under acidic conditions wherein the analyte was extracted from plasma by means of solid-phase extraction using C8 cartridges. This assay was successfully applied to plasma samples obtained from hypertensive patients [41]. In a modified solid-phase extraction, a poly (methacrylic acid-ethylene glycol dimethacrylate, MAA-EGDMA) monolithic capillary was used for extraction of CC from human plasma and urine. The method was demonstrated to be robust and biocompatible by using direct injections of biological samples [42].

In order to enhance the oral bioavailability of CC, a solid selfmicroemulsifying formulation was prepared. Initially, a liquid system was formulated using various combinations of lipid, emulgents and cosolvents. The liquid emulsifying system was then converted into free flowing powder by adsorption on solid carriers, i.e., microcrystalline cellulose and colloidal silicon dioxide. Finally in order to estimate the amount drug released during in vitro dissolution studies, a HPLC method was employed [43].

A HPLC method was employed for assessing the stability of CC in various types of cyclodextrin based formulations. It was found that
CC was stable at ambient conditions for 3 years as well as when stored in open containers at $40^{\circ} \mathrm{C} / 75 \% \mathrm{RH}$ and $50^{\circ} \mathrm{C} / 75 \% \mathrm{RH}$ for 3 months and 1 month, respectively. Also, Exposure to sunlight and UV light for 1 month similarly showed no loss in potency and absence of any degradation product [44].

In order to analyze the CC content in bulk substances and tablets, a gradient based HPLC method in isocratic mode was developed. During this process, $100.40 \%$ of CC was recovered from simulated tablets [45]. There are reports of two other simple and sensitive HPLC methods being developed and validated for determining CC in pharmaceutical dosage forms. Like the previous one, these methods were also run on isocratic mode [46,47]. A HPLC method was also applied for estimating the $\mathrm{CC}$ content during everted gut sac technique [48].

Over the years, many methods have been developed for the determination of CC in biological samples and pharmaceutical dosage forms based on LC-MS/MS method. It is a technique that combines the physical separation capabilities of liquid chromatography (or HPLC) with the mass analysis capabilities of mass spectrometry. Generally its application is focused on the general detection and potential identification of molecules or derivatives in a complex mixture [49-51]. Table 3 provides an account of various methods for the estimation of CC using LC-MS/MS method.

A combined electrospray and tandem mass spectrometry were used to characterize the conjugated metabolites (glucuronides) of CC in the plasma and bile of rats. This analysis was conducted to indentify the positional isomers with respect to the binding site of glucuronic acid. Thus, the simple chemical derivatization indicated the detailed structure of conjugated metabolite [52]. This combined spectrometry was also used to develop a method in human plasma with respect to simple sample clean-up and investigation of ion suppression effects. The developed method showed good precision and accuracy at different concentrations. The calculated LOD was quite low and CC was stable during the analytical process [53].

A high-throughput bioanalytical method for the analysis of CC in human plasma was developed and validated according to US FDA guidelines. The method was subsequently validated for precision and was stable under standard conditions with its ability to be applied successfully to oral pharmacokinetic study in humans [54].

During the development of a solid phase extraction procedure for the chromatographic determination, lack of linearity and reproducibility was observed for CC. As such a stability study was performed and it was found that lack of linearity and reproducibility was based on hydrolysis and trans-esterification processes. Subsequently, a detailed study was performed to assure that labile drugs containing ester groups remain unaffected [55].

In a study to evaluate the impact of high $\mathrm{pH}$ modifiers on the sensitivity of CC, LC-MS/MS under positive ESI (ESI+) was employed. The signal enhancement was two-fold compared with acidic modifiers and thus facilitated the development of a bioassay for the quantification of CC [56].

A method based on LC-MS/MS was developed to investigate the intravitreal toxicity and pharmacokinetics of candesartan and subsequent calculation of CC concentration in rabbit eyes [57].

A detailed stress degradation studies was conducted as per the ICH conditions of hydrolysis (acidic, basic and neutral), photolysis, 
Citation: Bandyopadhyay S, Bhuria L, Lal D (2013) An Explicit Review on Quantitative Estimation of Candesartan Cilexetil Employing Various Analytical Techniques. Pharm Anal Acta 4: 254. doi:10.4172/2153-2435.1000254

Page 4 of 7

\begin{tabular}{|c|c|c|c|c|c|c|c|}
\hline S. No. & Running Electrolyte & Solvent & Capillary & Voltage & Instrument & Detector & Reference \\
\hline 1. & $\begin{array}{l}50 \mathrm{mM} \text { potassium dihydrogen phosphate:boric acid }(25: 75 \mathrm{v} / \mathrm{v}, \mathrm{pH} 5.5) \\
\text { and at a } 5 \% \text { methanol }\end{array}$ & Methanol & Fused silica & $+25 \mathrm{kV}$ & $\begin{array}{l}\text { Waters Quanta } \\
4000\end{array}$ & UV $(214 \mathrm{~nm})$ & [32] \\
\hline 2. & $60 \mathrm{mM}$ sodium phosphate buffer $(\mathrm{pH} 2.5)$ & $1 \mathrm{M} \mathrm{HCl}$ & Fused silica & $25 \mathrm{kV}$ & Crystal CE & UV $(214 \mathrm{~nm})$ & [33] \\
\hline 3. & $\begin{array}{l}10-40 \mathrm{mM} \text { of mixture of a disodium hydrogenphosphate solution and a } \\
\text { sodium dihydrogenphosphate solution ( } \mathrm{pH} \text { range } 6.0-7.5)\end{array}$ & $0.1 \mathrm{M} \mathrm{NaOH}$ & Fused silica & $10 \mathrm{kV}$ & $\begin{array}{l}\text { Waters Quanta } \\
4000\end{array}$ & UV $(214 \mathrm{~nm})$ & [34] \\
\hline \multirow[t]{2}{*}{4.} & CZE Method: 60 mM sodium phosphate buffer ( $\mathrm{pH} 2.5)$ & $1 \mathrm{M} \mathrm{HCl}$ & \multirow{2}{*}{ Fused silica } & \multirow{2}{*}{$25 \mathrm{kV}$} & \multirow{2}{*}{ Crystal CE } & \multirow{2}{*}{ UV $(214 \mathrm{~nm})$} & \multirow{2}{*}{ [35] } \\
\hline & MEKC Method: $55 \mathrm{mM}$ sodium phosphate buffer (pH 6.5) & $0.1 \mathrm{M} \mathrm{NaOH}$ & & & & & \\
\hline
\end{tabular}

Table 1: An updated account on various Capillary Electrophoresis methods employed for the estimation of Candesartan cilexetil.

\begin{tabular}{|c|c|c|c|c|c|c|}
\hline $\begin{array}{l}\text { S. } \\
\text { No. }\end{array}$ & Type of Media & Column & Mobile Phase & Detector & $\begin{array}{l}\text { Chromatographic } \\
\text { conditions }\end{array}$ & Reference \\
\hline 1. & Human serum & $\begin{array}{l}\text { YMC ODS }(23 \times 4.0 \\
\mathrm{mm}) \\
\text { YMC ODS }(150 \times 4.6 \\
\mathrm{mm})\end{array}$ & $\begin{array}{l}\text { Phase A: Acetonitrile and potassium } \\
\text { dihydrogen phosphate }(20 \mathrm{mM}) \text { in ratio of } \\
60: 40, \mathrm{pH} 4.0 \\
\text { Phase B: Acetonitrile and dihydrogen } \\
\text { phosphate }(20 \mathrm{mM}) \text { in ratio of } 60: 40, \mathrm{pH} 6.0\end{array}$ & UV (229 nm) & $\begin{array}{l}\text { Flow rate: } 1.0 \mathrm{~mL} \cdot \mathrm{min}^{-1} \\
\text { Temperature: } 40^{\circ} \mathrm{C}\end{array}$ & [36] \\
\hline 2. & $\begin{array}{l}\text { Human serum } \\
\text { and urine }\end{array}$ & $\begin{array}{l}\text { Inertsil ODS-2 ( } 150 \times \\
4.6 \mathrm{~mm}, 5 \mu \mathrm{m})\end{array}$ & $\begin{array}{l}\text { First column: } 0.02 \mathrm{M} \text { potassium dihydrogen } \\
\text { phosphate Acetonitrile }(40: 60) \text { adjusted to } \\
\text { pH } 4.0 \text { with } 85 \% \text { orthophosphoric acid } \\
\text { Second column: } 0.02 \mathrm{M} \text { potassium } \\
\text { dihydrogen phosphate Acetonitrile }(40: 60) \\
\text { adjusted to } \mathrm{pH} 6.0 \text { with } 1 \mathrm{M} \mathrm{NaOH}\end{array}$ & $\begin{array}{l}\text { Fluorescence detector } \\
\text { (Excitation and Emission } \\
\text { wavelengths set at } 270 \text { and } \\
390 \mathrm{~nm} \text { ) }\end{array}$ & $\begin{array}{l}\text { Flow rate: } 1.0 \mathrm{~mL} \cdot \mathrm{min}^{-1} \\
\text { Temperature: } 40^{\circ} \mathrm{C}\end{array}$ & [37] \\
\hline \multirow{3}{*}{3.} & \multirow{3}{*}{$\begin{array}{l}\text { Human plasma } \\
\text { and urine }\end{array}$} & \multirow{3}{*}{$\begin{array}{l}\text { Spherisorb S3P } \\
(100 \times 4.6 \mathrm{~mm}, 3 \mu \mathrm{m} \\
\text { Hichrom })\end{array}$} & $\begin{array}{l}\text { Candesartan (Plasma): } \\
100 \mathrm{ml} \text { citrate buffer (pH } 3.1, \mathrm{l}=0.5 \\
\text { containing } 50 \mathrm{mM} \text { TBA), } 185 \mathrm{ml} \text { acetonitrile, } \\
180 \mathrm{ml} \text { methanol and diluting to } 1000 \mathrm{ml} \\
\text { with water }\end{array}$ & \multirow{3}{*}{$\begin{array}{l}\text { Fluorescence detector } \\
\text { (Excitation and Emission } \\
\text { wavelengths set at } 265 \text { and } \\
395 \mathrm{~nm} \text { ) }\end{array}$} & $\begin{array}{l}\text { Flow rate: } 0.9 \mathrm{~mL} \cdot \mathrm{min}^{-1} \\
\text { Temperature: room }\end{array}$ & \multirow{3}{*}[40]{} \\
\hline & & & $\begin{array}{l}\text { Candesartan cilexetil (Plasma \& urine): } \\
200 \mathrm{ml} \text { phosphate buffer (pH } 2.8, \mathrm{I}=0.1 \\
\text { containing } 12.5 \mathrm{mM} \text { TBA), } 420 \mathrm{ml} \\
\text { acetonitrile and diluting to } 1000 \mathrm{ml} \text { with } \\
\text { water }\end{array}$ & & $\begin{array}{l}\text { Flow rate: } 1.0 \mathrm{~mL} \cdot \mathrm{min}^{-1} \\
\text { Temperature: room }\end{array}$ & \\
\hline & & & $\begin{array}{l}\text { Candesartan (Urine): } \\
\text { Phase A: } 200 \mathrm{ml} \text { phosphate buffer (pH } \\
2.8, \mathrm{I}=0.1 \text { containing } 12.5 \mathrm{mM} \text { TBA), } 200 \\
\text { ml acetonitrile and diluting to } 1000 \mathrm{ml} \text { with } \\
\text { water } \\
\text { Phase B: } 200 \mathrm{ml} \text { phosphate buffer (pH } \\
2.8, \mathrm{I}=0.1 \text { containing } 12.5 \mathrm{mM} \text { TBA), } 600 \\
\text { ml acetonitrile and diluting to } 1000 \mathrm{ml} \text { with } \\
\text { water }\end{array}$ & & $\begin{array}{l}\text { Flow rate: } 1.0 \mathrm{~mL} \cdot \mathrm{min}^{-1} \\
\text { Temperature: room }\end{array}$ & \\
\hline 4. & Human plasma & $\begin{array}{l}\text { Novapak guard } \\
\text { column }(20 \times 39 \mathrm{~mm} \text {, } \\
4 \mu \mathrm{m}) \\
\text { muBondapak }(300 \times \\
3.9 \mathrm{~mm}, 10 \mu \mathrm{m})\end{array}$ & Acetonitrile $(5 \mathrm{mM})$ acetate buffer $(\mathrm{pH} 4)$ & $\begin{array}{l}\text { Fluorescence detector } \\
\text { (Excitation and Emission } \\
\text { wavelengths set at } 250 \text { and } \\
375 \mathrm{~nm} \text { ) }\end{array}$ & $\begin{array}{l}\text { Flow rate: } 1.0 \text { to } 1.2 \\
\mathrm{~mL} \cdot \mathrm{min}^{-1} \text { Temperature: } \\
\text { room }\end{array}$ & [41] \\
\hline 5. & $\begin{array}{l}\text { Human plasma } \\
\text { and urine }\end{array}$ & $\begin{array}{l}\text { Betasil }(250 \mathrm{~mm} \times \\
4.6 \mathrm{~mm}, 5 \mu \mathrm{m})\end{array}$ & $\begin{array}{l}\text { Acetonitrile and Sodium acetate buffer } \\
\text { solution }(5 \mathrm{mM}, \mathrm{pH} 3.5) \text { in the ratio of } 40: 60)\end{array}$ & $\begin{array}{l}\text { PDA }(250 \mathrm{~nm}) \text { and } \\
\text { fluorescence (Excitation and } \\
\text { Emission wavelengths set at } \\
250 \text { and } 380 \mathrm{~nm})\end{array}$ & Flow rate: $1.0 \mathrm{~mL} \cdot \mathrm{min}^{-1}$ & [42] \\
\hline 6. & $\begin{array}{l}\text { In vitro } \\
\text { dissolution }\end{array}$ & $\begin{array}{l}\text { Inertsil ODS-3 }(250 \times \\
4.6-\mathrm{mm}, 5 \mu \mathrm{m})\end{array}$ & $\begin{array}{l}0.02 \mathrm{M} \text { monobasic potassium phosphate, } \\
\text { acetonitrile, and triethylamine in the ratio } \\
\text { of } 40: 60: 0.2 \text { ( } \mathrm{pH} \text { adjusted to } 6.0 \text { using } \\
\text { phosphoric acid) }\end{array}$ & UV $(254 \mathrm{~nm})$ & $\begin{array}{l}\text { Flow rate: } 2.0 \mathrm{~mL} \cdot \mathrm{min}^{-1} \\
\text { Temperature: } 25^{\circ} \mathrm{C}\end{array}$ & [43] \\
\hline 7. & Stability studies & $\begin{array}{l}\text { Hypersil ODS }(250 \times \\
4.6 \mathrm{~mm}, 5 \mu \mathrm{m})\end{array}$ & $\begin{array}{l}0.02 \mathrm{M} \text { Potassium dihydrogen phosphate } \\
\text { solution and acetonitrile }(2: 8), \mathrm{pH} 4.0 \text { was } \\
\text { adjusted with } 85 \% \text { phosphoric acid }\end{array}$ & UV $(254 \mathrm{~nm})$ & $\begin{array}{l}\text { Flow rate: } 1.0 \mathrm{~mL} \cdot \mathrm{min}^{-1} \\
\text { Temperature: ambient }\end{array}$ & [44] \\
\hline 8. & Drug analysis & Zorbax SB-Phenyl & $\begin{array}{l}0.1 \mathrm{~mol}^{\mathrm{L}} \mathrm{L}^{-1} \text { sodium acetate }(\mathrm{pH} 5.5) \\
\text { acetonitrile and methanol in 10:9:6 v/v/v } \\
\text { ratio }\end{array}$ & UV $(230 \mathrm{~nm})$ & & [45] \\
\hline 9. & Drug analysis & $\begin{array}{l}\text { Hypersil ODS }(250 \times \\
4.6 \mathrm{~mm}, 5 \mu \mathrm{m})\end{array}$ & $\begin{array}{l}\text { Tetra butyl ammonium hydrogen sulphate } \\
10 \mathrm{mM}(\mathrm{pH} 3.37) \text { : methanol }(15: 85)\end{array}$ & UV $(270 \mathrm{~nm})$ & $\begin{array}{l}\text { Flow rate: } 1.0 \text { mL.min }{ }^{-1} \\
\text { Temperature: ambient }\end{array}$ & [46] \\
\hline 10. & Drug analysis & $\begin{array}{l}\text { Hypersil Phenyl } 2 \\
(250 \times 4.6 \mathrm{~mm}, 5 \mu \mathrm{m})\end{array}$ & $\begin{array}{l}0.02 \mathrm{M} \text { potassium dihydrogen phosphate, } \\
\text { methanol, and triethylamine }(25: 75: 0.2 \mathrm{v} / \mathrm{v}) \\
\mathrm{pH} 6.0 \pm 0.1 \text { was adjusted by addition of } \\
10 \% \text { orthophosphoric acid }\end{array}$ & UV $(271 \mathrm{~nm})$ & $\begin{array}{l}\text { Flow rate: } 1.0 \mathrm{~mL} \cdot \mathrm{min}^{-1} \\
\text { Temperature: room }\end{array}$ & [47] \\
\hline 11. & $\begin{array}{l}\text { Everted gut sac } \\
\text { (Rat) }\end{array}$ & $\begin{array}{l}\text { Shim-pack VP-ODS } \\
(150 \times 4.6 \mathrm{~mm}, 5 \mu \mathrm{m})\end{array}$ & $\begin{array}{l}\text { Acetonitrile: Methanol : water : glacial acetic } \\
\text { acid }(40: 35: 25: 0.1 \mathrm{v} / \mathrm{v}), \mathrm{pH} 6.8\end{array}$ & UV (255 nm) & $\begin{array}{l}\text { Flow rate: } 1.0 \mathrm{~mL} \cdot \mathrm{min}^{-1} \\
\text { Temperature: ambient }\end{array}$ & {$[48]$} \\
\hline
\end{tabular}

Table 2: An updated account on various HPLC analysis employed for the estimation of Candesartan cilexetil. 
Citation: Bandyopadhyay S, Bhuria L, Lal D (2013) An Explicit Review on Quantitative Estimation of Candesartan Cilexetil Employing Various Analytical Techniques. Pharm Anal Acta 4: 254. doi:10.4172/2153-2435.1000254

Page 5 of 7

\begin{tabular}{|c|c|c|c|c|c|c|}
\hline S. No. & Type of Media & HPLC Column & HPLC Mobile Phase & Mass Analyzer & Chromatographic conditions & Reference \\
\hline 1. & $\begin{array}{l}\text { Rat plasma and } \\
\text { bile }\end{array}$ & $\begin{array}{l}\text { AM-312 (ODS, } 150 \times 6 \\
\mathrm{~mm}, 5 \mu \mathrm{m})\end{array}$ & $\begin{array}{l}\text { Water-acetonitrile-trifluoroacetic } \\
\text { acid }(70: 30: 0.1 \mathrm{v} / \mathrm{v})\end{array}$ & Finnigan MAT (QqQ) & $\begin{array}{l}\text { Flow rate: } 1.0 \mathrm{~mL} \cdot \mathrm{min}^{-1} \\
\text { Temperature: ambient }\end{array}$ & {$[52]$} \\
\hline 2. & Rat plasma & $\begin{array}{l}\text { ACE C18 column }(50 \times \\
4.6 \mathrm{~mm}, 5 \mu \mathrm{m})\end{array}$ & $\begin{array}{l}10 \mathrm{mM} \text { ammonium } \\
\text { acetate:acetonitrile }(20: 80, \mathrm{v} / \mathrm{v})\end{array}$ & $\begin{array}{l}\text { MDS Sciex API } 4000 \\
(Q)\end{array}$ & $\begin{array}{l}\text { Flow rate: } 0.5 \mathrm{~mL} \cdot \mathrm{min}^{-1} \\
\text { Temperature: } 40 \pm 2^{\circ} \mathrm{C} \\
\text { Detection: PDA }(254 \mathrm{~nm})\end{array}$ & {$[54]$} \\
\hline 3. & Human plasma & $\begin{array}{l}\text { Synergy Polar RP }(150 \times \\
2 \mathrm{~mm}, 4 \mu \mathrm{m})\end{array}$ & $\begin{array}{l}\text { Solvent } \mathrm{A}: 0.1 \% \text { formic acid } \\
(\mathrm{v} / \mathrm{v}) \text { with } 1 \mathrm{mmol} / \mathrm{L} \text { ammonium } \\
\text { formate Solvent B: acetonitrile: } \\
0.1 \% \text { formic acid } 95: 5(\mathrm{v} / \mathrm{v}) \text { with } 1 \\
\mathrm{mmol} / \mathrm{L} \text { ammonium formate }\end{array}$ & API 365 (QqQ) & $\begin{array}{l}\text { Flow rate: } 0.25 \mathrm{~mL} \cdot \mathrm{min}^{-1} \\
\text { Temperature: } 40^{\circ} \mathrm{C}\end{array}$ & [55] \\
\hline 4. & Rabbit eyes & $\begin{array}{l}\text { Capcell Pak }(4.6 \times 250 \\
\mathrm{mm}, 5 \mu \mathrm{m})\end{array}$ & $\begin{array}{l}\text { Acetonitrile and water }(0.1 \% \\
\text { formic acid) }\end{array}$ & $6410(\mathrm{QqQ})$ & $\begin{array}{l}\text { Flow rate: } 1.0 \mathrm{~mL} \cdot \mathrm{min}^{-1} \\
\text { Temperature: room }\end{array}$ & [57] \\
\hline 5. & Stability studies & $\begin{array}{l}\text { Luna C18 }(150 \times 4.6 \mathrm{~mm} \text {, } \\
5 \mu \mathrm{m})\end{array}$ & $\begin{array}{l}\text { Acetonitrile and potassium } \\
\text { dihydrogen orthophosphate buffer } \\
\text { ( } \mathrm{pH} 2.8 ; 0.01 \mathrm{M}) \text { in a gradient } \\
\text { mode }\end{array}$ & MicrOTOF-Q (TOF) & $\begin{array}{l}\text { Flow rate: } 1.0 \mathrm{~mL} \cdot \mathrm{min}^{-1} \\
\text { Temperature: room Detection: } \\
\text { PDA }(254 \mathrm{~nm})\end{array}$ & [58] \\
\hline 6. & Impurity profile & $\begin{array}{l}\text { Kromasil cyano column } \\
(250 \times 4.6 \mathrm{~mm}, 5 \mu \mathrm{m})\end{array}$ & $\begin{array}{l}\text { Water adjusted to } \mathrm{pH} 3.0 \text { with } \\
\text { TFA }(\mathrm{A}) \text { and acetonitrile }(\mathrm{B}) \text { in a } \\
\text { gradient mode }\end{array}$ & PolarisQ (IT) & $\begin{array}{l}\text { Flow rate: } 1.0 \mathrm{~mL} \cdot \mathrm{min}^{-1} \\
\text { Temperature: room Detection: } \\
\text { PDA }(210 \mathrm{~nm})\end{array}$ & [59] \\
\hline 7. & Human plasma & $\begin{array}{l}\text { BEH C18, } 1.7 \mu \mathrm{m} \text { column } \\
\text { (analysis performed with } \\
\text { Acquity UPLC) }\end{array}$ & $\begin{array}{l}0.1 \%(\mathrm{v} / \mathrm{v}) \text { formic acid in Distilled } \\
\text { water and } 0.1 \%(\mathrm{v} / \mathrm{v}) \text { formic acid in } \\
\text { acetonitrile }(60: 40, \mathrm{v} / \mathrm{v})\end{array}$ & $\begin{array}{l}\text { Micromass Quattro } \\
\text { Premier XE }\end{array}$ & $\begin{array}{l}\text { Flow rate: } 0.4 \mathrm{~mL} \cdot \mathrm{min}^{-1} \\
\text { Temperature: room }\end{array}$ & {$[60]$} \\
\hline 8. & Rat plasma & $\begin{array}{l}\text { Zorbax SB-C18 }(150 \\
\times 4.6 \mathrm{~mm}) \text { with a C18 } \\
\text { guard column }(4 \times 3.0 \\
\mathrm{mm}, \text { Phenomenex })\end{array}$ & $\begin{array}{l}\text { Methanol and } 5 \mathrm{mM} \text { ammonium } \\
\text { acetate }(50: 50 \mathrm{v} / \mathrm{v})\end{array}$ & MDS Sciex API 4000 & $\begin{array}{l}\text { Flow rate: } 0.6 \mathrm{~mL} \cdot \mathrm{min}^{-1} \\
\text { Temperature: room Detection: } \\
\text { PDA }(254 \mathrm{~nm})\end{array}$ & [61] \\
\hline
\end{tabular}

Q: Single quadrupole, QqQ: Triple quadrupole, IT: Ion trap, TOF: Time of flight, Q-TOF: quadrupole-time of flight

Table 3: An updated account on various LC-MS/MS analysis employed for the estimation of Candesartan cilexetil.

oxidation and thermal stress. During the study, maximum degradation was observed on hydrolysis, especially in the neutral condition, followed by significant photolytic degradation. However, it was stable to oxidative and thermal stress. The method was able to provide an updated and comprehensive fragmentation behavior and degradation profile of CC [58].

During the impurity profiling in bulk drug samples, four impurities were detected in CC by HPLC and LC/MS. An optimized method using liquid chromatography coupled with electrospray ionization ion trap mass spectrometry was developed to elucidate the structures of these unknown impurities. The plausible mechanism for the formation of impurities was also discussed [59].

In an open-labeled, randomized, single dose, crossover design involving 40 healthy volunteers, various parameters of pharmacokinetics were determined. Also, the bioequivalence of two CC $16 \mathrm{mg}$ formulations were evaluated. The single dose study concluded that the test and reference products met the regulatory criteria for bioequivalence in the health volunteers [60].

Owing to poor aqueous solubility, CC undergoes incomplete intestinal absorption leading to low oral bioavailability. A novel CC loaded nanoemulsion was designed to improve the intestinal absorption. The concentration of active candesartan in rat plasma was determined by LC-MS/MS method. The experimental results showed an overall 10-fold improvement in oral absorption of insoluble CC and thus proving its potential for clinical applications [61].

\section{Conclusion}

Overall, various techniques were employed for the estimation of CC. Although the techniques viz. UV spectrophotometry, voltammetry and capillary electrophoresis are simpler and easier to apply yet they could not be applied for estimation in biological matrixes. HPLC method is an usual tool for the researcher, being mostly employed for routine analysis purpose. LC-MS/MS is used due to its high sensitivity and exceptional specificity compared to other method esp. when the sample is ionized and require shorter analysis time. Also, the optimum concentrations for therapeutic efficacy of many drug(s) range from a few nanograms to hundreds of nanograms per milliliter. In such cases, LC-MS/MS method provides a quality standard as per USFDA for therapeutic drug monitoring, clinical and forensic toxicology of drugs. Conclusively, modern instruments like, HPLC and LC-MS provides a simple, rapid and reliable method for quantification of candesartan and/or its metabolites which ultimately facilitate the in vitro and in vivo evaluations of candesartan.

\section{References}

1. Naka T (1993) Angiotensin II receptor antagonist activities and mode of action of benzimidazole-7-carboxylic acid derivatives. Nihon Rinsho 51: 1575-1579.

2. Mizuno K, Niimura S, Tani M, Saito I, Sanada H, et al. (1992) Hypotensive activity of TCV-116, a newly developed angiotensin II receptor antagonist, in spontaneously hypertensive rats. Life Sci 51: PL183-187.

3. McClellan KJ, Goa KL (1998) Candesartan cilexetil. A review of its use in essential hypertension. Drugs 56: 847-869.

4. Ross A, Papademetriou V (2004) Candesartan cilexetil in cardiovascular disease. Expert Rev Cardiovasc Ther 2: 829-835.

5. Mendis B, Page SR (2009) Candesartan: widening indications for this angiotensin II receptor blocker? Expert Opin Pharmacother 10: 1995-2007.

6. Sohn Y, Lee SY, Lee GH, Na YJ, Kim SY, et al. (2012) Development of selfmicroemulsifying bilayer tablets for $\mathrm{pH}$-independent fast release of candesartan cilexetil. Pharmazie 67: 917-924.

7. Vaculikova E, Grunwaldova V, Kral V, Dohnal J, Jampilek J (2012) Preparation of candesartan and atorvastatin nanoparticles by solvent evaporation. Molecules 17: 13221-13234.

8. Detroja C, Chavhan S, Sawant K (2011) Enhanced antihypertensive activity of candesartan cilexetil nanosuspension: formulation, characterization and pharmacodynamic study. Sci Pharm 79: 635-651.

9. Easthope SE, Jarvis B (2002) Candesartan cilexetil: an update of its use in essential hypertension. Drugs 62: 1253-1287.

10. van Lier JJ, van Heiningen PN, Sunzel M (1997) Absorption, metabolism 
and excretion of $14 \mathrm{C}$-candesartan and $14 \mathrm{C}$-candesartan cilexetil in healthy volunteers. J Hum Hypertens 11 Suppl 2: S27-28.

11. Gleiter $\mathrm{CH}$, Mörike KE (2002) Clinical pharmacokinetics of candesartan. Clin Pharmacokinet 41: 7-17.

12. Gleiter CH, Jägle C, Gresser U, Mörike K (2004) Candesartan. Cardiovasc Drug Rev 22: 263-284.

13. Hübner R, Högemann AM, Sunzel M, Riddell JG (1997) Pharmacokinetics of candesartan after single and repeated doses of candesartan cilexetil in young and elderly healthy volunteers. J Hum Hypertens 11 Suppl 2: S19-25.

14. Ripley TL, Chonlahan JS, Germany RE (2006) Candesartan in heart failure. Clin Interv Aging 1: 357-366.

15. Shibouta Y, Inada Y, Ojima M, Wada T, Noda M, et al. (1993) Pharmacological profile of a highly potent and long-acting angiotensin II receptor antagonist 2-ethoxy-1-[[2'-(1H-tetrazol-5-yl)biphenyl-4- yl]methyl]-1H-benzimidazole-7carboxylic acid (CV-11974), and its prodrug, (+/-)-1-(cyclohexyloxycarbonyloxy)ethyl 2-ethoxy-1-[[2'-(1H-tetrazol-5-yl)biphenyl-4-yl]methyl]-1H-benzimidazole7-carboxylate (TCV-116). J Pharmacol Exp Ther 266: 114-120.

16. Inada Y, Wada T, Shibouta Y, Ojima M, Sanada T, et al. (1994) Antihypertensive effects of a highly potent and long-acting angiotensin II subtype-1 receptor antagonist, (+-)-1-(cyclohexyloxycarbonyloxy)ethyl 2-ethoxy-1-[[2'-(1Htetrazol-5-yl)biphenyl-4-yl]methyl]-1 H- benzimidazole-7-carboxylate (TCV116), in various hypertensive rats. J Pharmacol Exp Ther 268: 1540-1547.

17. Naka T, Kubo K (1999) A new class of diacidic nonpeptide angiotensin I receptor antagonists: candesartan cilexetil. Curr Pharm Des 5: 453-472.

18. ATACAND® product monograph, http://www.astrazeneca.ca/documents/ ProductPortfolio/ATACAND PM en.pdf.

19. Nishikawa K, Inada Y, Shibouta Y, Wada T, Ojima M, et al. (1994) Pharmacological profile of a novel nonpeptide angiotensin II subtype 1 receptor antagonist, TCV-116. Blood Press Suppl 5: 7-14

20. Nishikawa K, Naka T, Chatani F, Yoshimura Y (1997) Candesartan cilexetil: a review of its preclinical pharmacology. J Hum Hypertens 11 Suppl 2: S9-17.

21. Hansen S, Pedersen-Bjergaard S, Rasmussen K (2011) Analysis of Drugs in Biological Fluids, in Introduction to Pharmaceutical Chemical Analysis. John Wiley \& Sons, Ltd.

22. Cagigal E, González L, Alonso RM, Jiménez RM (2001) pK(a) determination of angiotensin II receptor antagonists (ARA II) by spectrofluorimetry. J Pharm Biomed Anal 26: 477-486.

23. Erk N (2003) Application of first derivative UV-spectrophotometry and ratio derivative spectrophotometry for the simultaneous determination of candesartan cilexetil and hydrochlorothiazide. Pharmazie 58: 796-800

24. Pradhan KK, Mishra US, Pattnaik S, Panda CK, Sahu KC (2011) Development and Validation of a Stability-indicating UV Spectroscopic Method for Candesartan in Bulk and Formulations. Indian J Pharm Sci 73: 693-696.

25. Charooa NA, Bashira M, Abdallaa E, Alia KIH (2009) Determination of candesartan cilexetil in tablet dosage forms and dissolution testing samples by first derivative UV spectrophotometric method. Analytical Letters 42: 22322243.

26. Zoski CG (2007) Handbook of Electrochemistry. Elsevier Science. ISBN: 9780-444-51958-0.

27. Dogan B, Uslu B, Ozkan SA (2004) Anodic adsorptive stripping voltammetry of the antihypertensive drug candesartan cilexetil at a glassy carbon electrode. Pharmazie 59: 840-844.

28. Suslu I, Ozaltin N, Altinoz S (2009) Square-wave adsorptive stripping voltammetric determination of candesartan cilexetil in pharmaceutical formulations. J Appl Electrochem 39: 1535-1543.

29. Süslü I, Ozaltin N, Altinöz S (2010) Voltammetric determination of candesartan cilexetil in its $\mathrm{Cu}(\mathrm{II})$ complex and application to pharmaceutical formulations. J AOAC Int 93: 562-568.

30. Norouzi P, Pirali-Hamedani M, Ganjali MR (2013) Candesartan cilexeti determination by electrode modified with hybrid film of ionic liquid-graphene nanosheets-silicon carbide nanoparticle using continuous coulometric FFT cyclic voltammetry. Int J Electrochem Sci 8: 2023-2033.

31. Garcia CD, Chumbimuni-Torres KY, Carrilho E (2013) Capillary electrophoresis and microchip capillary electrophoresis: Principles, applications and limitations. John Wiley \& Sons, Inc., New Jersey.
32. González L, Akesolo U, Jiménez RM, Alonso RM (2002) Application of capillary zone electrophoresis to the screening of some angiotensin II receptor antagonists. Electrophoresis 23: 223-229.

33. Hillaert S, Van den Bossche W (2002) Optimization and validation of a capillary zone electrophoretic method for the analysis of several angiotensin-II-receptor antagonists. J Chromatogr A 979: 323-333.

34. Hillaert S, De Beer TR, De Beer JO, Van den Bossche W (2003) Optimization and validation of a micellar electrokinetic chromatographic method for the analysis of several angiotensin-II-receptor antagonists. J Chromatogr A 984: 135-146.

35. Hillaert S, Van den Bossche W (2003) Simultaneous determination of hydrochlorothiazide and several angiotensin-II-receptor antagonists by capillary electrophoresis. J Pharm Biomed Anal 31: 329-339.

36. Lee JW, Naidong W, Johnson T, Dzerk A, Miyabayashi T, et al. (1995) Development and validation of column-switching high-performance liquid chromatographic methods for the determination of a potent All recepto antagonist, TCV-116, and its metabolites in human serum and urine. $J$ Chromatogr B Biomed Appl 670: 287-298.

37. Miyabayashi T, Okuda T, Motohashi M, Izawa K, Yashiki T (1996) Quantitation of a new potent angiotensin II receptor antagonist, TCV-116, and its metabolites in human serum and urine. J Chromatogr B Biomed Appl 677: 123-132.

38. Malerczyk C, Fuchs B, Belz GG, Roll S, Butzer R, et al. (1998) Angiotensin I antagonism and plasma radioreceptor-kinetics of candesartan in man. $\mathrm{Br} \mathrm{J}$ Clin Pharmacol 45: 567-573.

39. Fuchs B, Breithaupt-Grögler K, Belz GG, Roll S, Malerczyk C, et al. (2000) Comparative pharmacodynamics and pharmacokinetics of candesartan and losartan in man. J Pharm Pharmacol 52: 1075-1083.

40. Stenhoff H, Lagerström PO, Andersen C (1999) Determination of candesartan cilexetil, candesartan and a metabolite in human plasma and urine by liquid chromatography and fluorometric detection. J Chromatogr B Biomed Sci App 731: 411-417.

41. González L, López JA, Alonso RM, Jiménez RM (2002) Fast screening method for the determination of angiotensin II receptor antagonists in human plasma by high-performance liquid chromatography with fluorimetric detection. J Chromatogr A 949: 49-60.

42. Nie J, Zhang M, Fan Y, Wen Y, Xiang B, et al. (2005) Biocompatible in tube solid-phase microextraction coupled to HPLC for the determination of angiotensin II receptor antagonists in human plasma and urine. J Chromatogr B Analyt Technol Biomed Life Sci 828: 62-69.

43. Nekkanti V, Karatgi P, Prabhu R, Pillai R (2010) Solid self-microemulsifying formulation for candesartan cilexetil. AAPS PharmSciTech 11: 9-17.

44. Al Omari AA, Al Omari MM, Badwan AA, Al-Sou'od KA (2011) Effect of cyclodextrins on the solubility and stability of candesartan cilexetil in solution and solid state. J Pharm Biomed Anal 54: 503-509.

45. Czerwiß̊,ska K, Mazurek AP (2011) Identification and determination of selected angiotensin II receptor antagonist group drugs by HPLC method. Acta Pol Pharm 68: 831-837.

46. Annapurnaa MM, Narendra A, Kumar KR (2012) Liquid chromatographic method for the simultaneous quantitative determination of candesartan cilexetil and hydrochlorthiazide in pharmaceutical dosage forms. J Drug Deliv Thera 2: $48-54$.

47. Qutab SS, Razzaq SN, Ashfaq M, Shuja ZA, Khan IU (2007) Simple and sensitive LC-UV method for simultaneous analysis of hydrochlorothiazide and candesartan cilexetil in pharmaceutical formulations. Acta Chromato 19: 119129.

48. Gurunath S, Nanjwade BK, Patila PA (2013) Enhanced solubility and intestina absorption of candesartan cilexetil solid dispersions using everted rat intestinal sacs. Saudi Pharm J.

49. Mück W (1999) Quantitative analysis of pharmacokinetic study samples by liquid chromatography coupled to tandem mass spectrometry (LC-MS/MS) Pharmazie 54: 639-644.

50. Niwa M (2012) Chemical derivatization as a tool for optimizing MS response in sensitive LC-MS/MS bioanalysis and its role in pharmacokinetic studies. Bioanalysis 4: 213-220.

51. Jian W, Edom RW, Xu Y, Weng N (2010) Recent advances in application of 
Citation: Bandyopadhyay S, Bhuria L, Lal D (2013) An Explicit Review on Quantitative Estimation of Candesartan Cilexetil Employing Various Analytical Techniques. Pharm Anal Acta 4: 254. doi:10.4172/2153-2435.1000254

hydrophilic interaction chromatography for quantitative bioanalysis. J Sep Sci 33: 681-697.

52. Kondo T, Yoshida K, Yoshimura Y, Motohashi M, Tanayama S (1996) Characterization of conjugated metabolites of a new angiotensin II receptor antagonist, candesartan cilexetil, in rats by liquid chromatography/electrospray tandem mass spectrometry following chemical derivatization. J Mass Spectrom. 31: 873-878.

53. Ferreirós N, Dresen S, Alonso RM, Weinmann W (2007) Validated quantitation of angiotensin II receptor antagonists (ARA-II) in human plasma by liquidchromatography-tandem mass spectrometry using minimum sample clean-up and investigation of ion suppression. Ther Drug Monit 29: 824-834.

54. Bharathi DV, Hotha KK, Chatki PK, Satyanarayana V, Venkateswarlu V (2012) LC-MS/MS method for simultaneous estimation of candesartan and hydrochlorothiazide in human plasma and its use in clinical pharmacokinetics. Bioanalysis 4: 1195-1204.

55. Ferreirós N, Dresen S, Alonso RM, Weinmann W (2007) Hydrolysis and transesterification reactions of candesartan cilexetil observed during the solid phase extraction procedure. J Chromatogr B Analyt Technol Biomed Life Sci 855: 134-138.
56. Mess JN, Lahaie M, Furtado M, Garofolo F (2009) Effect of high pH mobile phase on the sensitivity of multiple drugs by LC positive electrospray ionization MS/MS. Bioanalysis 1: 1419-1430.

57. Lee JE, Lim DW, Park HJ, Shin JH, Lee SM, et al. (2011) Intraocular toxicity and pharmacokinetics of candesartan in a rabbit model. Invest Ophthalmol Vis Sci 52: 2924-2929.

58. Mehta S, Shah RP, Priyadarshi R, Singh S (2010) LC and LC-MS/TOF studies on stress degradation behaviour of candesartan cilexetil. J Pharm Biomed Anal 52: 345-354.

59. Raman B, Sharma BA, Mahale G, Singh D, Kumar A (2011) Investigation and structural elucidation of a process related impurity in candesartan cilexetil by LC/ESI-ITMS and NMR. J Pharm Biomed Anal 56: 256-263.

60. Jeon JY, Im YJ, Kim Y, Han SM, Jo MJ, et al. (2012) Pharmacokinetic properties and bioequivalence of candesartan cilexetil in Korean healthy volunteers. Drug Dev Ind Pharm .

61. Gao F, Zhang Z, Bu H, Huang Y, Gao Z, et al. (2011) Nanoemulsion improves the oral absorption of candesartan cilexetil in rats: Performance and mechanism. J Control Release 149: 168-174. 